\title{
Labor Competitiveness in Digital Economy: A Systematic Review of College Graduates
}

\author{
Efni Cerya ${ }^{1}$ And Jusmanila Mustika S. ${ }^{2}$ \\ ${ }^{1}$ Dept. of Economics Education, Faculty of Economics, Universitas Negeri Padang, Indonesia \\ $\triangle$ (e-mail) efnicerya@gmail.com \\ ${ }^{2}$ Universitas Andalas, Padang, Indonesia $\bowtie$ (e-mail) jusmanilamustika@gmail.com
}

\begin{abstract}
The aims of this paper are to identify and to analyze some key references on labor competitiveness in digital economy. This study is a systematic riview which employs four phases: (1) the identification of relevant studies with the use of several keywords such as labor competitiveness; (2) the description of the position of the Indonesian labor competitiveness based on the data from the World Bank-OECD, International Labor Organization (ILO), United Nations Development Program (UNDP) and the Indonesian Central Bureau for Statistics (BPS); (3) the identification of factors that affect the competitiveness of Indonesian workers, and the formulation of recommendations for the government policy to increase the competitiveness of Indonesian workers. The results of this study find that the education sector becomes one of the priorities to be reformed. The government should be able to provide affordable secondary and higher education for the community, without neglecting the quality of the education. There should be a synchronization between the educational institutions and the industry needs so that graduates of secondary and tertiary education would not end up become educated unemployment with low competence.
\end{abstract}

Keywords: labor competitiveness, education quality, competence

\section{Introduction}

Globalization unites the world into an integrated entity. It starts with a shift from Globalization Phase 1.0, Phase 2.0, Phase 3.0, to the current Phase 4.0, or what is known now as the Digital Age. In expanding a country's economic potential, the new economy or digital economy is based more in the form of intangibles, information, innovation, and creativity, (Persaud, 2001) and it is based on the exploitation of ideas rather than goods.

The industrial revolution is not only about international economics and trading issues but also refers to other issues, such as democratization, science, technology, information, education and also the human capital. The workforce has become one of the central issues in this industrial revolution phase 4.0. The human capital becomes an input for the sustainability of the new economic era. In the digital age, the workers are required to possess professional skills in terms of the ability to innovate and be creative in order to compete in the international markets.

Indonesia as one of the countries with abundant human resources has the number of the workforce that reaches 128.30 million (BPS, 2017). The most crucial problems faced by the Indonesian is related to the empowerment of the human resources. In 2017, The Indonesian 
Central Bureau for Statistics (BPS) states that there is approximately 7 million workforce who are under open unemployment.

Although the Indonesian migrant workers (TKI) are classified as the most aggressive labor in the international market, with the number of the TKI reaching 3.5 million workers, these workers are generally working in the informal sector with low skills. This condition is different from that of around 126 thousand expatriate workers (TKA) who work in Indonesia, as they occupy positions as managers or engineers/professionals who require expertise in their fields.

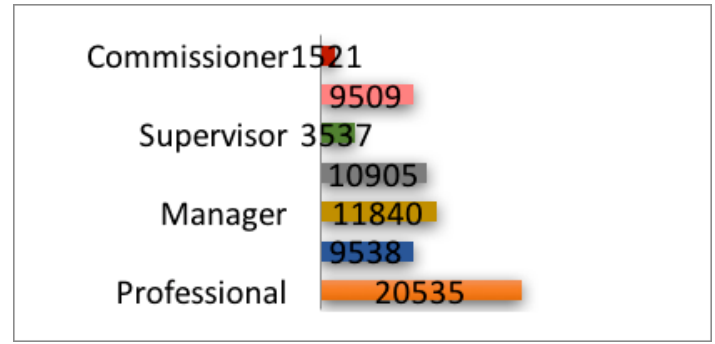

Source: Indonesian Ministry of Manpower and Transmigration

Figure 1 Expatriate workers based on their position levels in 2016

Porter (1994) emphasizes the importance of human capital in the form of the quantity that also needs to be supported with the highly qualified ability to master science and technology. The workforce has become the main determinant in establishing a nation's competitiveness. The World Economic Forum (2017) in its release on The Global Competitiveness Report has set the labor as one of the indicators of a nation's competitiveness among other pillars of global competitiveness.

Results of empirical studies (Ermina, 2014) also indicate that there is a strong relationship between the workforce competitiveness and the economic competitiveness. This means that to improve the competitiveness of a nation, it is important to increase the competitiveness of its workforce.

Based on the above descriptions, the authors conducted a descriptive study on the position of competitiveness of the Indonesian workers compared to workers in other countries, and on factors that influence the competitiveness of Indonesian workers. The objective of this study is to formulate clear and systematic implementation steps to encourage the competitiveness of Indonesian workers. Also, this study is expected to provide suggestions for the stakeholders in terms of policies that could increase the competitiveness of Indonesian workers.

\section{Methods}

The systematic literature review employs four phases: (1) the identification of relevant studies with the use of several keywords such as labor competitiveness; (2) the description of the position of the Indonesian labor competitiveness based on the data from the World Bank -OECD, International Labor Organization (ILO), United Nations Development Program (UNDP) and the Indonesian Central Bureau for Statistics (BPS); (3) the identification of factors that affect the competitiveness of Indonesian workers, and the formulation of 
recommendations for the government policy to increase the competitiveness of Indonesian workers.

The authors compared and analyzed the relevant data and information from the World Bank, the Organization for Economic Cooperation and Development (OECD), the International Labor Organization (ILO), United Nations Development Program (UNDP), and the Indonesian Central Bureau for Statistics (BPS).

\section{Results and Discussion}

\section{Labor Competitiveness}

There is no standard definition for competitiveness. There are many definitions of competitiveness when viewed from various perspectives and levels of analysis. OECD (2016) defines the competitiveness as "the ability of companies, industries, regions, nations, and supranational regions to generate while being and remaining exposed to the international competition, relatively high factor income, and factor employment levels on a sustainable basis".

The World Economic Forum (2012) defines the competitiveness as a combination of institutions, policies, and factors that determine the level of productivity of a country. The level of productivity will determine the level of prosperity achieved by the nation's economy. Competitiveness measurements are often used to determine the nation's ability to compete with other countries.

Umar Chandhiq (2006) states that a nation's low level of competitiveness could lead to a dependence on other nations which will reduce the capability of the nation's supremacy.

Furthermore, Potter (2006) believes that competitiveness is the foundation of prosperity of a nation, based on the potential of economic productive of the country, which is ultimately determined by the productivity of the companies in the country, which in turn is determined by the sophisticated operations and corporate strategy; and the environment quality of the microeconomic business.

Competitiveness is a multidimensional concept that involves many different aspects, including the comparative advantages, competitive advantages, business strategies and business results (Waheeduzzaman, 2011), reflecting that (Porter, 1990) the prosperity is not inherited, but is created and depends on the ability to innovate and improve the industry.

\section{Conceptual Blocks and Measurement of National Competitiveness}

This study discussed the competitiveness of Indonesian labor by finding out the competitiveness performance and the determinants of competitiveness. In the competitiveness of the labor performance, the role of Indonesian labor through their part in the world population, the labor productivity and the competitive advantage of the Indonesian labor are also analyzed. For the labor competitiveness determinants, it is decided that the determinants dimension follows a report based on the global competition index in the pillars of labor market efficiency.

The definition of the effective competition must include a long-term view of sustainable growth, whether in a company, industry, cluster, region or national level. This must be linked to fundamental goals such as creating wealth, welfare maximization and prosperity. 
Developing competitiveness should also take into account the development of relative efficiency along with sustainable growth. Competitiveness should also be understood as a process, not as an absolute state.

\section{Indonesian National Competitiveness}

The 2017-2018 Global Competitiveness Report released by the World Economic Forum to measure the level of competitiveness 137 countries economy through 12 economic pillars delegated Indonesia at the 36th rank among 137 countries, with the score of 4.68 or the 4th among the ASEAN countries after Singapore, Malaysia, and Thailand.

Table 1 Indonesia's competitiveness according to the Global Competitiveness Index 20172018

\begin{tabular}{ccc} 
Country (2017) & Rank & Value \\
Singapore & 3 & 5.71 \\
Malaysia & 23 & 5.17 \\
Thailand & 32 & 4.72 \\
Indonesia & 36 & 4.68 \\
Brunei & 45 & 4.52 \\
Vietnam & 55 & 4.36 \\
Philippines & 56 & 4.35 \\
\hline
\end{tabular}

Source: World Economic Forum (Processed)

Indonesia excels only in the pillar of market size, macroeconomic environment and innovation, ranking 9th, 26th and 31st respectively. Meanwhile, Indonesia's competitiveness is still lagging in the technology readiness, health and basic education and the labor efficiency, ranking 90th, 94th and 96th out of 137 countries, respectively.

\section{Indonesian Labor Competitiveness}

In measuring the labor competitiveness, the labor productivity becomes one of the indicators. The World Bank (2009) defines the competitiveness as a transformation process and an enhancement of constant added value per unit of output. Porter (1990) also defines the competitiveness as productivity: the output value produced by the labor.

Table 2 Per Worker Labor Productivity

\begin{tabular}{lcc}
\hline $\begin{array}{c}\text { ASEAN } \\
\text { Countries }\end{array}$ & Productivity & $\begin{array}{c}\text { Avarage Annoual } \\
\text { Productivity Growth (\%) }\end{array}$ \\
\hline Singapura & 128.8 & 2.5 \\
\hline Malaysia & 55.7 & 2.9 \\
\hline Philippines & 18.1 & 2.1 \\
\hline Thailand & 26.5 & 3.2 \\
\hline Indonesia & 24.3 & 3.1 \\
\hline Lao & 11.1 & 4.7 \\
\hline Viet Nam & 9.6 & 5.0 \\
\hline Cambodia & 5.7 & 4.1 \\
\hline Myanmar & 5.7 & 2.9 \\
\hline Brunei & 167.3 & -1.1 \\
\hline
\end{tabular}


Increasing the labor productivity will enhance the country's economic growth. Based on the data from the Asian Productivity Organization (APO), the study presents the productivity per worker in the Asian countries, especially the ASEAN countries. Table 2 presents the productivity per worker among the ASEAN countries.

Per Worker Labor Productivity is measured in units of USD \$. As seen in the table above, Singapore is the highest country with Per Worker Labor Productivity among the ASEAN countries, followed by Malaysia, Philippines, and Thailand. Indonesia only ranks as the 5th with USD \$24.3 productivity and the Average Annual Productivity Growth of 3.2\%. Even Brunei, which has high productivity nominal, experienced annual growth decline with an average of $1.1 \%$ per year.

Based on the comparison of the labor productivity ratio of other ASEAN countries to the labor productivity of Singapore, Indonesia has a quite huge ratio gap. Indonesian labor productivity is only one per 219 of Singapore's labor productivity. This is also experienced by other ASEAN countries.

\section{Competitive Advantage of Indonesian Labor}

At the macroeconomic level, the growth rate of Indonesia's overall employment has been decreasing. Figure 2 shows the changes in Indonesia's employment since 2001. While the total number of jobs has been steadily increasing, the growth rate shows a clear tendency of slowing down.

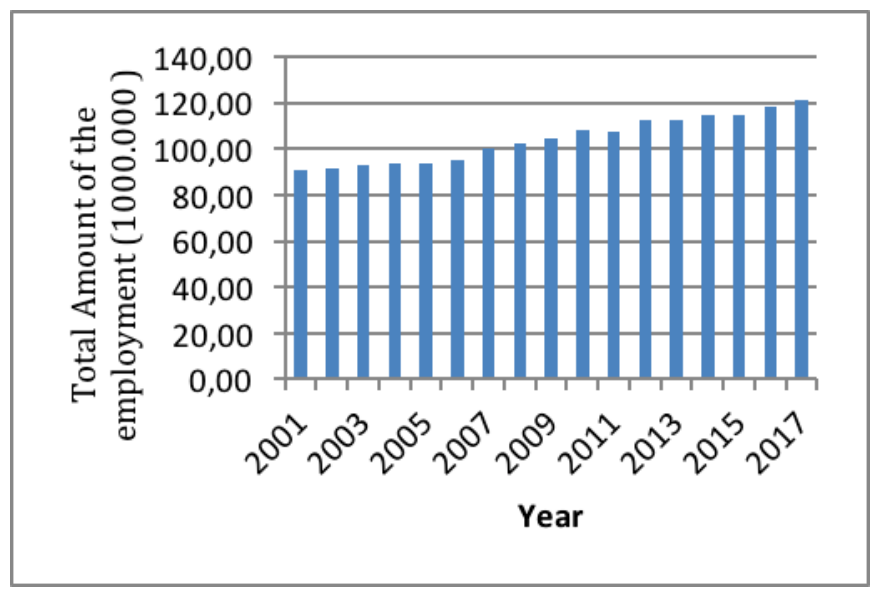

Source: Indonesian Central Bureau of Statistics

Figure 2 Total employment in Indonesia

Based on the above data, the annual increase in labor growth is not followed by the increase in national productivity as indicated in the economic growth. In general, the growth of an economic entity relies on factor input in the earlier stage of industrialization, but depend more on technology advancement after the initial stage (Lin and Sun, 2003).

For a developing country, labor becomes an important input factor on the steady economic growth, followed by the technological advancement that will accelerate the growth rate. With the technological revolution phase 4.0 or the digital age already on its way, workforce are required to have competencies and a good knowledge mastery. 


\section{Determinants of Indonesian Labor Competitiveness}

\section{The Composition of the Workforce Education}

Education is one of the important pillars that stimulate an increase in productivity (Todaro and Smith, 2015). Education opens the opportunity for both technical and cognitive knowledge and skills accumulation as the important determinants to increase productivity (World Bank, 2010a; Adam and Negara, 2015). Several empirical studies (such as Corvers, 1997; Jones, 2001; Rehman and Mughal, 2013) showed that the increase in education levels positively correlate with the increase in the levels of productivity.

Education has become an aspect of the development of human resources. Berker (1993) stated that human capital at the organizational level is composed of a number of components, including health care, migration, and training and development. Among those components, the education, experience, knowledge, and skill have been considered as the most important components that determine workforce productivity and labor compensation (Becker, 1993; Li and Ding, 2003).

Data from the Indonesian Central Statistics Bureau in 2017 on the composition of educational qualification of Indonesian workforce presented that the majority of the Indonesian labor is still dominated by elementary and middle school graduates, while higher education graduates such as diplomas and university graduates only amounted to 12 percent.

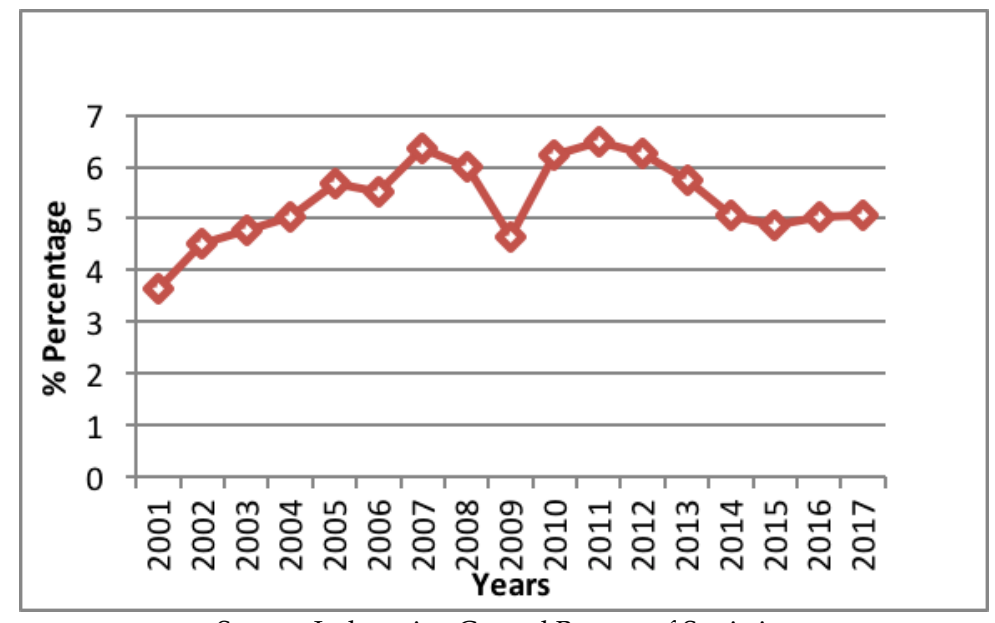

Source: Indonesian Central Bureau of Statistics

Figure 3 Growth rate of Indonesian productivity

Based on the findings, it can be seen that the structure of the Indonesian workforce is still dominated by elementary school graduates. The World Bank (2010) stated that the labor with elementary education has low qualifications in knowledge and skills. A country will face difficulty in competing with other countries if the majority of the workforce only have the qualification of elementary education because in general, they could only work in the informal sector with low productivity. 


\section{Labor Market Inefficiency}

In the National Competitiveness, the efficiency of Indonesian labor is the weakest pillar. Out of other 12 competitiveness pillars, the labor efficiency is the weakest pillar, which demonstrates inefficiencies in the Indonesian labor market.

The world's most famous index for a global recruiter, Hays Global Skill Index, defines that the labor market efficiency will occur when there is a trending gap of inequality between the company's need for skilled labor and the quality of the workforce.

Tabel 3 Index Component the $7^{\text {th }}$ Pillar: Indonesian labor market inefficiency

\begin{tabular}{lrr} 
7th plllar: Labor market efflclency & 96 & 3.9 \\
7.01 Cooperation in labor-employer relations & 41 & 4.7 \\
7.02 Flexibility of wage determination & 99 & 4.5 \\
7.03 Hiring and firing practices & 25 & 4.5 \\
7.04 Redundancy costs weeks of salary & 133 & 57.8 \\
7.05 Effect of taxation on incentives to work & 28 & 4.5 \\
7.06 Pay and productivity & 22 & 4.7 \\
7.07 Reliance on professional management & 34 & 4.8 \\
7.08 Country capacity to retain talent & 32 & 4.3 \\
7.09 Country capacity to attract talent & 25 & 4.5 \\
7.10 Female participation in the labor force ratio to men & 113 & 0.62 \\
\hline
\end{tabular}

This condition is indicated by the increase in the needs for labor and the number of unemployment even though there are still many unoccupied job opportunities in some sectors (beritasatu.com). Data from the Indonesian Central Bureau for Statistics in August of 2017 stated that 618 thousand or $8.8 \%$ unemployed workforce came from higher-education graduates.

Tabel 4 Index Component the $5^{\text {th }}$ Pillar: Higher education and training

\begin{tabular}{lll}
\hline 5th pillar: Higher education and training & 64 \\
5.01 Secondary education enrollment rate gross \% & 85 & 85.8 \\
5.02 Tertiary education enrollment rate gross \% & 33 & 4.4 .3 \\
5.03 Quality of the education system & 40 & 4.6 \\
5.04 Quality of math and science education & 42 & 4.6 \\
5.06 Quality of management schools & 45 & 4.8 \\
5.06 Internet access in schools & 45 & 4.7 \\
5.07 Local availability of specialized training services & 30 & 4.6 \\
5.08 Extent of staff training & & 1.6 \\
\hline
\end{tabular}

There is an irrelevance between the education and employment, which in this case between the quality of education graduates and the available jobs. This gap widens with the massiveness of the higher education and the poor absorption of the workforce by the industry. Michael Porter (2001) defines labor market efficiency as the effort to ensure that the workforce could be allocated into the most efficient use with the proper incentives, high mobility and a compensation system that is not distorted by social problems and is equal in gender. 
Similar to the aspect of education, The Global Competitiveness index 2017-2018 released by the World Economic Forum only places the pillars of Higher education and training on the 64th rank.

The Higher Education and Training pillar is also explained by several index components. Among these components, the Secondary education enrollment rate and the Tertiary education enrollment rate ranked as the lowest ratings (85th and 91st).

Compared to other ASEAN countries, Indonesia still falls behind Singapore, Malaysia, Philippines, and Thailand in the Higher Education and Training pillar ranking.

Table 5 Ranking of the higher education and training of ASEAN countries

\begin{tabular}{cll}
\hline No. & Country & Rank \\
\hline 1. & Singapore & 1 \\
\hline 2. & Malaysia & 45 \\
\hline 3. & Philippines & 55 \\
\hline 4. & Thailand & 57 \\
\hline 5. & Indonesia & 64 \\
\hline 6. & Brunei & 67 \\
\hline 7. & Viet Nam & 84 \\
\hline 8. & Laos & 105 \\
\hline 9. & Cambodia & 124
\end{tabular}

\section{Recommendations}

\section{Advancing the National Higher Education}

The Higher Education plays a role in accelerating the improvement of the human resources quality in the globalization era of the digital economy. Higher education institutions are experiencing the systematic changes in the response to the global developments.

The studies about the impact on the higher education as triggered by globalization, which were conducted by several researchers, have identified the following changes of direction in higher education:

- massification of higher education;

- change in higher education management (privatization included);

- change in responsibility and accountability for the quality of higher education;

- internationalization of education; and

- ranking of higher education institutions (Shin and Harman, 2009, p. 3)

The experts of the World Bank note that even though higher education and other public sector institutions compete with each other for the state budget funding, the financing of higher education from these resources remains important for three reasons:

1) the investment in higher education provides benefits in terms of economic and

2) social development;

3) the market disadvantages largely influence inaccessible loans to part of the

4) students; and

5) higher education is important for the development of basic and secondary 
6) education (Constructing Knowledge Societies, 2002, p. 76).

To promote the advancement of the higher education in accordance to the global demands, several aspects that need to be of concern include:

1) The Structure of Curriculum

The curriculum should be oriented towards the demands of the industrial revolution phase 4.0. Industrial Revolution 4.0 is an era of technological disruption with high demands on technological mastery, so that the previous Literacy, such as reading, writing, mathematics is irrelevant. The newly developed literacy is 1) the ability to read, analyze and use data information in the digital world, 2) Technology literacy in comprehending how the devices and applications technology work and 3) Human Literacy which includes skills in social interaction, communication, and design.

2) The Skills of the Educators

In supporting to establish a competent and globally competitive human capital, the educators are required to possess core competencies that are relevant to the needs of industry 4.0. Educators are expected to change the conventional methods in the lecturing process into the technology-based learning methods by applying the Hybrid/Blended Learning \& Online rooting systems.

\section{Implementing the Framework of National Qualification}

The framework of qualification is an instrument that classifies a person's qualifications as based on a set of criteria associated with the learning outcomes that he has obtained. Tuck (2007) describes that the existence of a framework of national qualification is expected to encourage the development of the workers' skills, facilitate the students' and workforce mobility and increase one's access to higher education and training throughout his life.

The Indonesian National Qualification Framework (KKNI) has become a reference for the educational and job training sectors to produce workers who have national and international qualifications. As a product of regulation, produced by the government long before the launch of the ASEAN Economic Community (MEA), The KKNI is expected to anticipate various problems that arise in relation to the human resources quality in the international labor market.

The document of KKNI that has been formulated since 2009 must be optimally implemented within:

1) Education

As a reference in the preparation of the curriculum. The KKNI -based curriculum is expected to produce workforce as demanded by the industry

2) Training

As part of non-formal education, the learning outcomes produced by Training implementing The KKNI refer to; 1) Skills, 2) Affection, 3) Competence. This training will be standardized with the legality of the Professional Certification Institution whose task is to ensure the quality of the certified workforce produced by the Indonesian educational or professionals training institutions.

The output of this educational process will produce learning outcomes which are manifested in the form of the Certificate of Competency. The Certificate of Competency is defined as a written evidence issued by an accredited professional certification agency 
which states that a person has mastered certain working competencies in accordance to the KKNI.

3) Industry

The Industrial Association or the User in industry is the user of the workforce that graduates from education and training institutions. The KKNI will be the reference for industry associations and industrial user to estimate the qualifications possessed by the job seekers and to position them at relevant career level and provide appropriate remuneration.

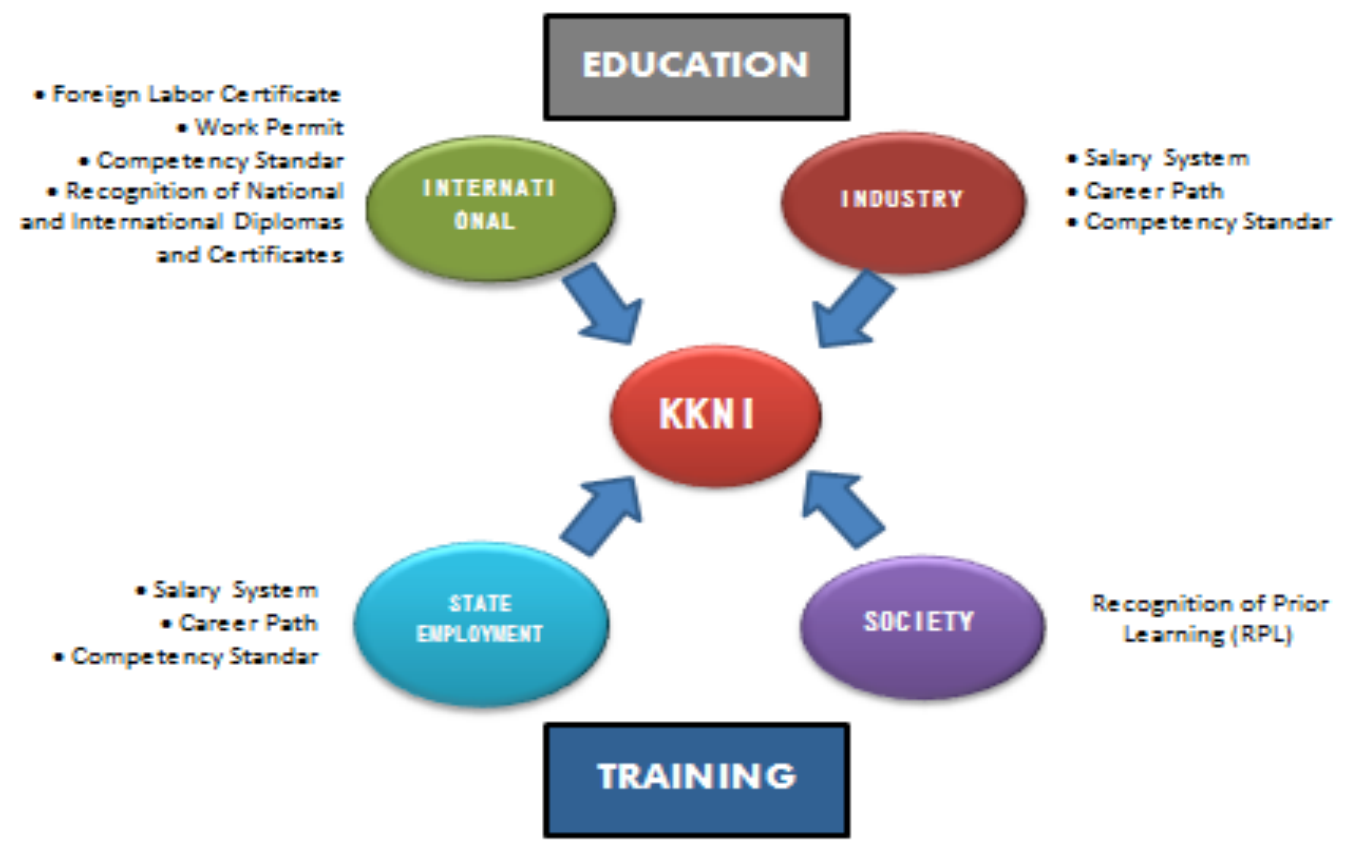

Figure 4 The connection between various sectors in the KKNI

The synchronization between the educational institutions, training institutions, and the industry will lead to the efforts to produce highly qualified human capital whose competencies have been approved both nationally and internationally. The gap between the quality of the graduates from the educational and training institutions, and the industrial needs will be overcome by optimizing the implementation of the Indonesian National Qualification Framework (KKNI).

\section{Conclusions}

The labor competitiveness determines the competitiveness of the nation. Indonesia as a country with a high-density population has the potential to compete with other countries; however, the high-density workforce should be supported with a good human capital quality. The development of Indonesia's human resources relatively still falls behind some ASEAN countries.

The development of human resources is a necessity that needs to be implemented immediately by the Indonesian Government. Rapid changes in the globalization era and the 
start of industrial revolution 4.0 force Indonesia to possess competent, innovative and highly competitive human capital. Due to the effort in increasing the competitiveness of the workforce, it will be necessary to have a planning with a structured and systematic process.

In this context, the education sector becomes the main goal that must be reformed. The government should be able to provide affordable secondary and higher education for the community, without neglecting the quality of the education. There should be a synchronization between the educational institutions and the needs of the industry so that graduates of secondary and tertiary education do not become educated unemployment with low competence.

The Indonesian National Qualification Framework (KKNI) which was formulated in 2009 has been bridging the gap between the educational institution and the industry. This document needs to be implemented in its concrete steps. The implementation in the educational institutions is by ensuring the curriculum, as the reference in the education process, to be compatible with the qualification framework. The industries as the user of the workforce have to ensure that workers with certain levels of education and competence are positioned to a suitable responsibility and an appropriate remuneration.

\section{References}

APO. (2015). APO Productivity Data Book. Tokyo: Asian Productivity Organization.

Becker, G.S. (1993). Human Capital: A Theoretical and Empirical Analysis with Special Reference to Education 3rd ed. University of Chicago Press, Chicago, IL.

ILO \& ADB. (2014) ASEAN Community 2015: Managing Integration for Better Jobs and Shared Prosperity. Thailand: ILO dan ADB.

Lai, D. (1998). Education, labor market and income distribution. Economic Research Journal. No. 2, pp. 42-9.

Persaud, A. (2001). The knowledge gap. Foreign Affairs, 80(2), 107-117.

OECD (1994). Globalisation and Competitiveness: Relevant Indicators. Paris : OECD Directorate for Science, Technology and Industry.

Porter, M. (1990). Competitive Advantage on Nation. New York: Free Press.

Porter, M., Ketels, C. and Delgado, M. (2006). The microeconomic foundations of prosperity: findings from the business competitiveness index, in Lopez-Claros, A., Porter, M., Sala-i-Martin, X. and Schwab, K. (Eds), The Global Competitiveness Report 2006-2007, World Economic Forum.

UNDP. (2015). Human Development Report Work for Human Development 2015. New York: United Nation Development Programme.

World Bank. (2017). Global Competitiveness Report 2009. Washingthon: the World Bank.

World Economic Forum. (2017). Global Competitiveness Report. Geneva: World Economic Forum. 